\title{
SWAMI VIVEKANANDA: AS A SOCIAL REFORMER
}

\author{
Jagabandhu Sarkar \\ M.A. in Philosophy, Visva-Bharati, Santiniketan
}

Article DOI: https://doi.org/10.36713/epra6023

\begin{abstract}
Swami Vivekananda was the pioneer of the $19^{\text {th }}$ century renaissance by religious revolution in India. He was one of the foremost leaders who were very much concerned about the poor and subjugated persons of the society. Vivekananda realized that there is need of reformation in society. Vivekananda wanted to revive the lost confidence of the common people in society. He visited extensively within the country to understand their problem. He wanted to eliminate all the social evils of the society which are major obstacles for the mankind. These social evils are poverty in general, untouchability, illiteracy, intolerance, religious superstitions etc. He always pleaded for the fraternity, humanity and harmony. He realized that the ultimate goal can be achieved through self-development of human values, not only by laws. In this short discourse, I would like to highlight Vivekanada's philosophical realization towards the mankind and his ideo of Rerormation.

KEYWORDS-Reformation, Untouchability, Self-realization, Harmony, Humanism, Brahman, Narayana, Brotherhood.
\end{abstract}

\section{INTRODUCTION}

The movement of Renaissance and reformation started before the freedom movement in India. The movement was flourished under the patronage of the great Indian leaders like Raja Rammohan Roy, Ishwar Chandra Vidyasagar, Swami Vivekananda, Rabindranath Tagore, Mahatma Gandhi and other persons. Their expressions and views were also verified in the context of the movement. They wanted to revive the social values which were greatly declined during this period which were held in high esteem, previously. The decline of social values was due to some retarding factors like caste system, oppressions by dominant authorities, social prohibition and lack of confidence. Vivekananda wanted to revive the lost confidence of the common people in society. He wanted to serve for the society through dedicating himself to the betterment of the society. He wanted to find the existence of God within the sorrows of the common people.

Vivekananda was the first leader who thought about the subdued section of the society. Vivekananda realized the virtue of reformation of the society. Reformation is constructive and novel in nature rather than destructive. It contains patient, sympathetic and hopeful attitude of the common people. He clearly distinguished between constructive and destructive ideas of reformation. Destructive reformation only affects the surface of the thing. Though some initial gains can be achieved through it, ultimately the evil and abuse appropriates the gains in the long run. $\mathrm{He}$ believed that everyone should go down to the root of the thing, which he calls 'radical reform'. He also opined that the solution of the problem is a vast process. It goes through the process of creation and construction and time is the only solution of this natural process.

Among these, Vivekananda accepts the method of construction which is based on two concepts. In one way he tried to remove the sorrows by spreading the sense of love to the down-trodden people of the society. In other way he tried to improve the cultural sense of the human beings. He realized that the ultimate social goal can be achieved through self-development of human values, not only by laws. These two views are inter-related to each other. In this context he cited the reference to civilization where he tried to explain that the ultimate development of the society depends upon the well-being of the people.

He visited extensively within the country to understand their problem. He believed that the main cause of Indian downfall was the neglect exploitation of the poor. He wanted to eliminate all the social evils of the society which are major obstacles for the mankind. These social evils are poverty in general, 
untouchability, illiteracy, intolerance, religious superstitions etc. He always pleaded for the harmony and good relationship. Swami Vivekananda dedicated himself to society; his aim was to serve to the common people. He said, through education, we should gradually reach the idea of universal brotherhood. Swami Vivekananda expressed forcing over exploitation of rights and uplift of women and other backward people. He wanted a independent social reform with the help of Western concepts and technology. He believes that all evils may be conquered by love which is real, living force of mankind.

That time India had been undergoing an extreme anarchy, the social condition was getting contaminated with poverty, exploitation, oppression, rich-poor discrimination. Vivekananda took place at that time. He took all the initiatives in order to eliminate this anarchy from the society. The origin of his religious and spiritual thoughts was human welfare. He had used humanism as his weapon in order to merge work with life. He demonstrated the path from darkness to light. According to him, the idealism of humanity is bestowed in sacrifice and service. The principle of humanity is entrusted in the well-being of all and this should be the way out for getting the initiations towards humanism. The main perspective of his life was to serve for mankind.

Vivekananda is the first socialist of India. But we like to add that he is the first socialist of the world having a spiritual orientation. Practical Vedanta teaches us that socialism is not enough to bring a nation into one whole unless it is rooted in spiritual commitments. Vivekananda says that Truth is eternal and nobody can lay any special claim to it. All theories or theologies, ratiocinations or metaphysical speculations may be illuminating in their own way. But all these have little importance, if they fail to touch the heart, the inner feelings of man, the reality. ${ }^{1}$

As mentioned in the 'Advaitavedanta' that life if nothing but the 'Brahman'. According to Sri Ramakrishna, life is only the part of 'Brahman' and the manifestation of the physical existence of 'Brahman'. "Yatra Jeeva Tatra Shiva", that is, to serve for life is to serve for God. He perceived the existence of God in every matter, in every life. In his philosophy of humanity, Vivekananda had exploited the Sri Ramakrishna's conception of service to mankind. He preached the views of Sri Ramakrishna all over the world. 'Brahman' is existing in every living things, hence, to serve for life is to serve for the 'Brahman'.

Sri Chaitanyadeva thought about kindness towards every organism. Sri Ramakrishna induced Vivekananda not to believe in kindness but to serve for life with the belief of serving to 'Lord Shiva'. Vivekananda acquired the philosophy of life from Lord Sri Ramakrishnadeva, the divine. He realized the need of wisdom as well as that of love, affection and sympathy for social reformation. Nothing is larger than human. It is mandatory to admire human irrespective of richness and poverty, in order to live a veritable life. This admiration can be made meaningful through love and service. That is not only by means of selfrealization, but also by amalgamating your own life with others' life. He refrained himself from eternal pleasures, and led an ordinary life. He was associated with the poor, the exploited and with the people of every tier of society that made him realize that the average part of the society is suppressed with adversity. But these very people are the backbone of the nation. He thought that the nation can't be built up unless they are awakened, until they are made our own. Vivekananda was saying, your life is for everyone, you are not born for yourself. Assign yourself towards serving the poor and exploited people.

Vivekananda always advised to extend our service for caring others, for the welfare of others. He advised to engage ourselves in extending our attachment with others. The origin of the thoughts of equality and unity belongs to love, respect and compassion to others. We all are equal and we all are the manifestations of the one and only 'Parama Brahma'. Loving others is to loving yourself. No difference between 'me' and 'others' was detected in the aspect of Vivekananda. Vivekananda used to find 'Narayana' everywhere in his inner sense andelevated invocation and even in all kinds of people like cobbler, sweeper etc. If this 'Narayana' in guise of human is not loved, then there is no way for ascension. Those are not humans who do not weep for humans, who cannot love humans, who try to draw a boundary line of intangibility. The absolute idealism of human life is to feel the existence of 'Shiva' (that is God) in humans. When Vivekananda was in abroad then he came across with the scientific justifications of comprehensive human welfare. On the other hand he was shocked with the poor and miserable condition of his fellow countrymen. As a result, he founded 'The Ramakrishna Math and Ramakrishna Mission' when he came back to India.

The perspective of this religious association was to promote true righteousness and social welfare. The aim was to rejuvenate the idealism of equality in human welfare, amity, and brotherhood. He realized that the base of righteousness is the act towards mankind. The ultimate idealism of Vivekananda was selfless service to all.

Vivekananda was the real social reformer. He emerged in order to reform the society, and not to distort it. He used to find God in human beings; he worshipped only human beings as his God. The poor, tortured and starved people were the ultimate God to him; humanity was the ultimate righteousness to him. 
He observed religion as the source of human welfare. It can only be expressed in honesty and in spiritual purity.

He was ready to quit everything in order to establish humanity. He says that "We are all human beings; but some are men, and some are women, Here is black man, there is a white man; but all are men, all belings to one humanity, Various are our faces; I see no two alike, yet we are all human. Where is this one humanity? I find a man or a woman, either dark or fair; and among all these faces I know that there is an abstract humanity which is common to all. I may find it when I try to grasp it, to sense it, and to actualize it, yet I know for certain that it is there. If I amsure of anything, it of this humanity which is common to us all. It is through this generalized entry that I see you as a man or a woman.',2

He believed that serving others is to serve self. He used to say that we should be grateful to those who have provided us the opportunity to serve them. He also believed that one can be transformed to have the deity power by means of continuous selfless service, and this way the world full with spite would become a heaven. He used to say that wearing the saffron colour can hardly be the condition of becoming a saint. Saints are those in general who have quit all the eternal pleasures by dedicating themselves into spiritual pursuit. This type of saints has detached themselves from their families and has got isolated themselves from the society also. But Vivekananda thinks that a saint should have detachment from his family but he should have to be associated with the society simultaneously. Providing service to the society is the prerequisite according to him. A saint should devote himself in extending his service towards human welfare. He spread the flavor of love and brotherhood to the entire mankind. He had overcome the borderline of narrowness in order to stand beside the people.

Swami Vivekananda had the firm conviction that India is full of endless spiritual potentialities and that these potentialities could not be actualized if man does not know himself, does not grow fearlessly having faith in his own actions and his service to his fellow beings, because all are one and within all dwells the same supreme spirit which is above all conflicts. ${ }^{3}$

\section{CONCLUSION}

Vivekananda is the first one who could find God in humans by serving them. On the other hand mankind also got the inspiration to live from his vicinity. According to him, human being is the creation of the one and only almighty. He also believed that charity begins at home, that is, by extending service to his fellow countrymen; one can extend his service to the people of all over the world. His dream was to build his nation by such citizens who would learn the lesson of sacrifice and would extend service to mankind. He desired to present a philosophy of life to mankind that would consist of love-integration-sacrifice-enthusiasm and determination. He desired to serve people with the help of this philosophy of life irrespective of racecaste-religion. This philosophy of life of Vivekananda has the capability to pioneer the right way to the confused people of the country and to show the path towards peace. He always chanted the conquest of humanity. Humanity and service are complimentary to each other according to him. The summit of humanity can only be reached by means of service. Preaching of humanity and caring and its extension needs to be spread from one nation to another. These spiritual messages of Vivekananda should substantively stick our heart, be sought in everyone's voice and be manifested in our act.

\section{REFERENCES}

1. The Philosophy of Swami Vivekananda. Pradip Kumar Sengupta( Editor) P-6

2. The Complete works of Swami Vivekananda. Mayavati Memorial Edition. Advaita Ashrama. Kolkata. 2008. P-381

3. The Philosophy of Swami Vivekananda. Pradip Kumar Sengupta( Editor) P-4

\section{BIBLIOGRAPHY}

1. The Complete works of Swami Vivekananda.(Mayavati Memorial Edition).Advaita Ashrama. Kolkata. 2008.

2. The Philosophy of Vivekananda and the Future Man, Govinda Chandra Dev, Ramkrishna Mission, Dacca, Pakisthan, 1963. .

3. Understanding Vivekananda, Amiya Kumar Mazumdar, Sanskrit Pustak Bhandar, Kolkata, 1973.

4. 4.Man the Known and Man the Unknown, Swami Ranganathananda, Ramkrishna Math, Chennai, 2006.

5. The Philosophy of Swami Vivekananda, Pradip Kumar Sengupta (Editor) Progressive Publishers, Kolkata, Reprint-2012.

6. Contemporary Indian Philosophy, B. K. Lal, Motilal Banarsidass Publishers, Delhi, 2002.

7. Understanding Vivekananda, Amiya Kumar Mazumdar, , Sanskrit Pustak Bhandar, Kolkata, 1973. 